Mass Sensor

Federal Manufacturing \& Technologies

B. E. Adams

KCP-613-6363

Published January 2001

Final Report/CRADA Project Accomplishments Summary

CRADA Number 98KCP1070

Approved for public release; distribution is unlimited.

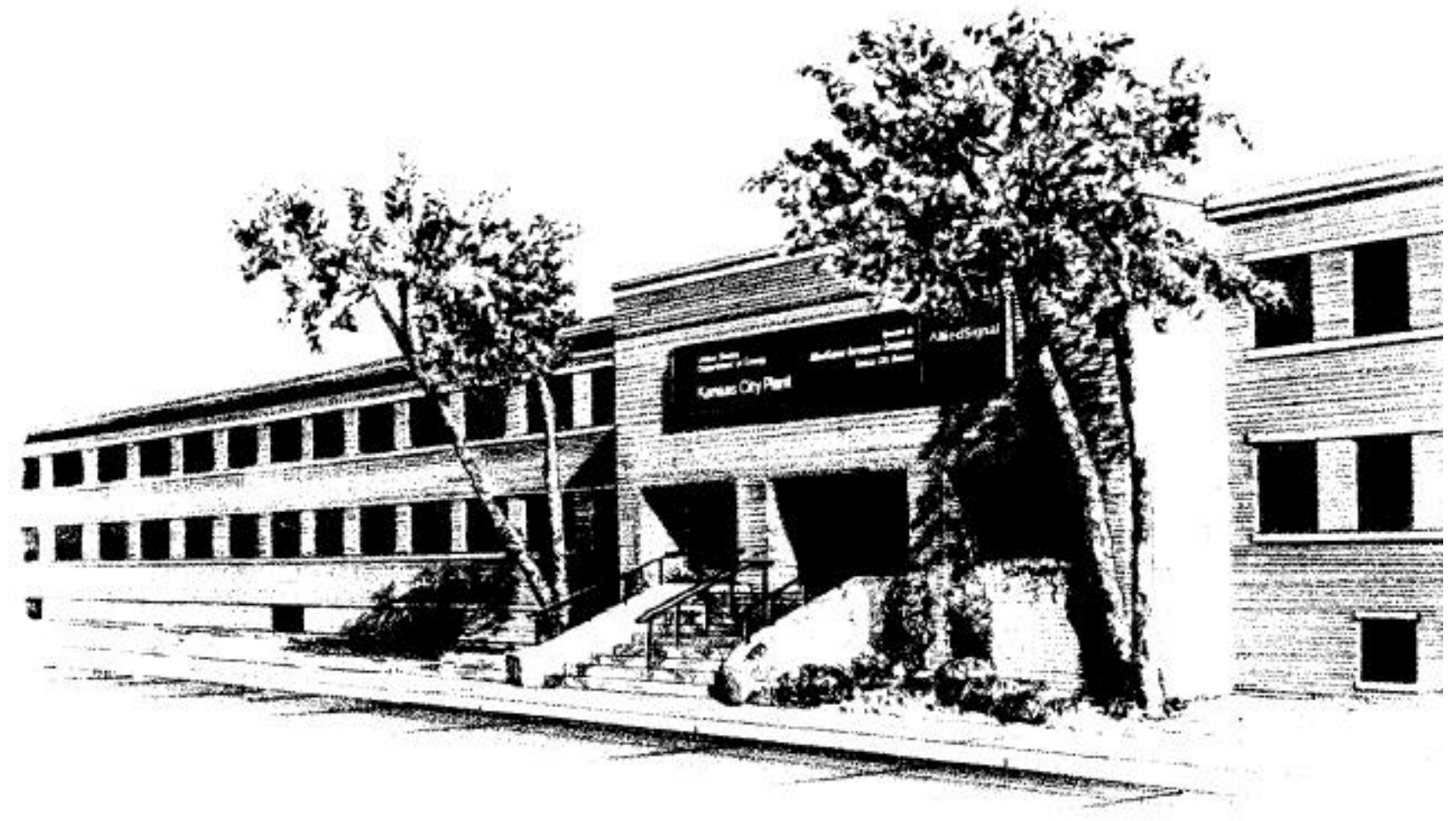

Prepared Under Contract Number DE-ACO4-76-DP00613 for the

United States Department of Energy 


\section{DISCLAIMER}

This report was prepared as an account of work sponsored by an agency of the United States Government. Neither the United States Government nor any agency thereof, nor any of their employees, makes any warranty, express or implied, or assumes any legal liability or responsibility for the accuracy, completeness, or usefulness of any information, apparatus, product, or process disclosed, or represents that its use would not infringe privately owned rights. Reference herein to any specific commercial product, process, or service by trade names, trademark, manufacturer, or otherwise, does not necessarily constitute or imply its endorsement, recommendation, or favoring by the United States Government or any agency thereof. The views and opinions of authors expressed herein do not necessarily state or reflect those of the United States Government or any agency thereof.

Printed in the United States of America.

This report has been reproduced from the best available copy.

Available to DOE and DOE contractors from the Office of Scientific and Technical Information, P. O. Box 62, Oak Ridge, Tennessee 37831; prices available from (865) 576-8401, FTS 626-8401.

Available to the public from the National Technical Information Service, U. S. Department of Commerce, 5285 Port Royal Rd., Springfield, Virginia 22161, (703) 487-4650.

A prime contractor with the United States

Honeywell

Federal Manufacturing

\& Technologies

P. O. Box 419159

Kansas City, Missouri

Department of Energy under Contract Number

64141-6159

DE-ACO4-76-DP00613.

Honeywell

KCP-613-6363

Distribution Category UC-706

Approved for public release; distribution is unlimited. 


\title{
MASS SENSOR
}

\author{
B. E. Adams
}

Published January 2001

Final Report/Project Accomplishments Summary

CRADA Number 98KCP1070

\section{MASS SENSOR}

\author{
Project Accomplishments Summary
}

CRADA Number 98KCP1070

Date: $7 / 15 / 2000$

Revision:
A. Parties

The project is a relationship between

Honeywell International Inc.

2000 E $95^{\text {th }}$ Street

PO Box 419159

Kansas City, MO 64141-6159

Mass Sensors, LLC

PO Box 12466

St. Louis, MO 63132

\section{B. Background}

The current state-of-the-art mass spectrometer is a large, non-mobile piece of laboratory equipment, requiring samples of gases to be delivered directly to the unit. This project was based upon a mobile hand-carry system with the ability to "sniff" the air and identify the components. The analyzer was to be approximately one inch square and $1 / 4$ inch thick. Mass Sensors had a patented design which they were interested in fabricating using ceramic materials. Honeywell had experience fabricating electronic networks on ceramic. The analyzer was an extension of this technology. 


\section{Description}

The purpose of this CRADA was to use Honeywell's experience in low temperature cofire ceramics and traditional ceramics to assemble a relatively low-cost, mass-producible miniature mass analyzer. The specific design, given to us by Mass Sensors, LLC, was used to test for helium.

\section{Expected Economic Impact}

The direct benefit for the participant was to have a prototype unit assembled for the purpose of proof of concept and the ability to secure venture capital investors. From that, the company would begin producing their own product for sale. The consumer/taxpayer benefits come from the wide variety of industries that can utilize this technology to improve quality of life. Medical industry can use this technology to improve diagnostic ability; manufacturing industry can use it for improved air, water, and soil monitoring to minimize pollution; and the law enforcement community can use this technology for identification of substances. These are just a few examples of the benefit of this technology.

\section{E. Benefits to DOE}

The benefits to DOE were in the area of process improvement for cofire and ceramic materials. From this project we demonstrated nonlinear thickfilm fine lines and spaces that were 5-mil wide with 5-mil spaces; determined height-to diameter-ratios for punched and filled via holes; demonstrated the ability to punch and fill 5-mil microvias; developed and demonstrated the capability to laser cut difficult geometries in 40-mil ceramic; developed and demonstrated coupling LTCC with standard alumina and achieving hermetic seals; developed and demonstrated three-dimensional electronic packaging concepts; and demonstrated printing variable resistors within $1 \%$ of the nominal value and within a tightly defined ratio.

\section{F. Industry Area}

The capability of this device makes it invaluable for many industries. The device could be used to monitor air samples around manufacturing plants. It also could be used for monitoring automobile exhaust, for doing blood gas analysis, for sampling gases being emitted by volcanoes, for studying activities of insects, and many other things.

\section{G. Project Status}

The ultimate goal was to build two iterations of the mass sensor. However, due to technical difficulties, only one iteration of the device was manufactured. Initial work to optimize the ion source and build a small ion pump was not successful. Consequently, the ion pump was not incorporated into the analyzer design. Mass Sensors, LLC, is still testing the analyzers that were assembled.

\section{H. Point of Contact for Project Information}

\section{Ken Bauer}

US Department of Energy

Kansas City Area Office 
PO Box 410202

Kansas City, MO 64141-0202

Telephone: (816) 997-3917

Fax: (816) 997-5059

Bryan Adams

Honeywell International Inc.

PO Box 419159

Kansas City, MO 64141-6159

Telephone: (816) 997-4914

Fax: (816) 997-3297

I. Company Size and Point of Contact

This is a start-up company. The point of contact is Phil Burger at 314-997-7156.

\section{J. Project Examples}

Mechanical samples, a stereolithographic replica made at the 5X scale, and photos of each part of the analyzer are the only examples of the device.

Figure 1 is a photo at the final assembly.

K. Technology Commercialization

The successful conclusion of this project was one of the early steps taken by Mass Sensors, LLC, for securing venture capital to start up a company with this as its product. Mass Sensors is still in the development stages, but envisions building a large successful company based upon their design of a miniature mass spectrometer. 


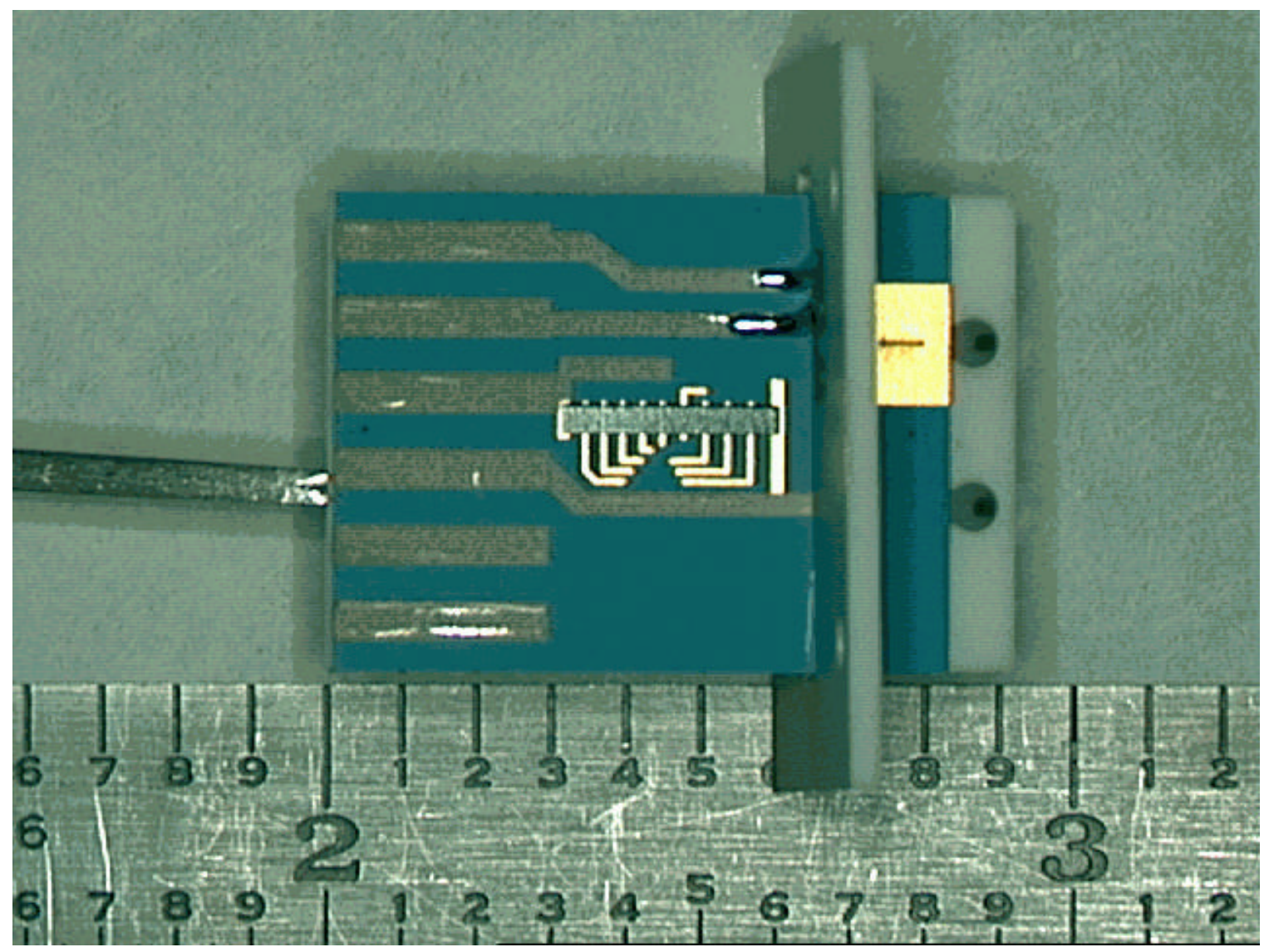

Figure 1. Mass Analyzer 